'Manipulation School' presents us with a new paradigm which prefers to put its emphasis not on interlinguistic relations but rather on intertextual ones; likewise, instead of centring its attention on potential translation or translatability, prefers to analyse translations which have already been done." Dr. Vidal brilliantly examines the philosophical foundations of this school of traductological thought and analyses in detail several of its basic concepts, among which is that of polysystem.

The third chapter, entitled "Desconstruir la traducción," is a work of applied theory. Here the author is on home ground, manipulating with ease and familiarity her own reflections on post-structuralism, Jacques Derrida's deconstruction and their application to translation.

To summarize all the foregoing, we can definitely state that whether one agrees or disagrees with the postulates of the questions examined, in particular those of the Manipulation School, or with the contribution made by post-structuralism and deconstruction to traductology, it is eminently true that the specialised reader will not remain indifferent to the imaginative analysis offered with full academic rigour by Dr. Vidal. All her personal reflection on the science and the art of translation is contained in the three chapters entitled "Sobre el estado de la cuestión," "La traducción como manipulación," and "Desconstruir la traducción," which are accompanied by abundant footnotes whose erudition and accuracy provide a solid intellectual base for what she affirms elsewhere, as well as helping the reader to discover new pathways for research into the theory of translation. The book ends with a wide-ranging yet select, up-to-date bibliography of works on translationand in particular on the questions analysed. This bibliography is highly valuable as a basic research instrument for advanced students of translation.

At the same time as we offer our gratitude to Dr. Vidal Claramonte for this new contribution to the world of the intellect, we should also like to make it clear that in our opinion Translation, manipulation, deconstruchon is a valuable conceptual work which should occupy its rightful place on the theory of translation bookshelf, alongside the great theoreticians of translation such as Nida, Vázquez Ayora, Bassnett, Lefevre, Santoyo, Rabadán, Peña, Hurtado and others; the author has courageously approached translation in a serious, confident, academically rigorous manner and from an interdisciplinary standpoint.

Enrique Alcaraz Varó

Diccionario de uso inglés-español/Spanish-English. Directed by Aquilino Sánchez. Madrid: SGEL, 1993, 450 pp. • Diccionario de uso pocket inglés-español/SpanishEnglish. Directed by Aquilino Sánchez. Madrid: SGEL, 1993, 274 pages.

Very often, and perhaps as a result of the false cliché that would make us believe that any product coming from abroad must be better, those of us who have made English a way of life let only a limited series of publishers control the field of English teaching and translation. This has led us, on the one hand, to believe that any textbook published in 
Britain is better and, on the other, that we are to dismiss all dictionaries made in Spain, in such a way that the books used in Britain in classes of Spanish as a foreign language had been made in England (the famous Calatrava series), while the materials we used with our students also came from English-speaking publishers.

Fortunately, it has been shown that, as far as textbooks and grammars are concerned, a contrastive view is necessary, and the mother language of a student has a bearing on the way he or she will learn English, which means that some structures will need more insistence than others (for example, conditionals are almost similar in English and Spanish, whereas French speakers are likely to encounter more difficulties). In the case of dictionaries, the times in which infamous word-lists with false friends were mercilessly circulated are over, and the work we are dealing with might well be the best response to the avalanche of English-Spanish dictionaries made in Britain which, despite their obvious merits, cannot help being a tool for English-speaking students who desire to learn Spanish, and therefore fail to give sufficient explanations of the pitfalls of the English language.

The authors of this dictionary, under the wise direction of Professor Aquilino Sánchez, from the University of Murcia, have clearly wished to create a useful working instrument, and this is why little frequent forms which would be of little use to language learners. In this way a detailed treatment of the lexical units is achieved, similar to the one that may be found in larger dictionaries, especially in the case of idiomatic examples which cannot be found in traditional repertoires, such as ancha es Castilla or para más inri, which show also the needs of foreign learners of Spanish have been taken into account.

In the organization of entries, a criterium can be traced which we had already seen in German dictionaries, as the same entry gives access to apartado, apartamento and apartar, which certainly entails a departure from the usual procedure, but allows the learner or translator to have a better grasp of the word family.

Another of the details that show that the authors actually wish to offer a useful tool is the exhaustive and accurate allophonic description of Spanish, which is counterparted by an excellent summary of English phonetics in the introduction, miles better than the traditional statement " $p$ como en pato" that was given in many dictionaries, which did not even mention the aspiration of voiceless plosives in initial position. In fact, it has given us a great pleasure to see how Spanish authors have overcome the usual inactivity when it comes to teaching Spanish as a foreign language, and we have reasons to confirm this is a good dictionary of Spanish usage, which makes us believe that it will be successful also among foreign learners.

Such desire to produce a dictionary of usage comes to the foreground in entries such as añoranza, the translation of which proposes longing, yearning, nostalgia on the one hand and hankering on the other, but also mentions the prepositions, for y after respectively (as we would find in a monolingual dictionary), in order to avoid the Spanish learner's temptation to use of. Also, the fact that the authors have accepted the challenge of including a syllabic division of English, which causes trouble even among native speakers, shows us that producing a practical dictionary often entails facing difficulties and successfully overcoming them. 
There is wide evidence that shows the validity of this work, such as the translation of juez instructor as examining magistrate, the accuracy of which is similar to that of the versions offered by lawyers and experts in Legal English and Legal Spanish, or the translation of hardware and software for soporte fisico and soporte logico, respectively, in line with the proposal of the Spanish Real Academia de la Lengua. Nevertheless, the authors do not want to be excessively prudish, and are willing to offer alternative spellings in Spanish, such as euskera/eusquera, which might probably displease Spanish purists, but most certainly will prevent a great deal of perplexity among English-speaking readers of Spanish contemporary newspapers.

Finally, an analysis of a dictionary as a working instrument must necessarily mention its presentation. This work has a handy, resistent format, which enables learners to use it in the classroom, thus avoiding the burden of larger volumes, which leads to have a more reduced version for frequent use and a more detailed one for written translation and homework. The same can be said about the pocket edition. All these features result in two useful, complete and accurate dictionaries, which can be perfectly used an alternative to the most frequent works we all have in mind.

Miguel Ángel Campos Pardillos

\section{La presencia ausente: perspectivas interdisciplinares de la posmodernidad. Ed. Román Álvarez Rodríguez. Cáceres: Servicio de Publicaciones de la Universidad de Extremadura, 1994, 192 pp.}

It might seem that postmodernism is on the wane, or at least that it has lost some of its initial seductive force, replaced by a-very postmodern-sense of indefinition and disenchantment, the feeling that the absence of secure positions will not, unfortunately, lead to any confident procedure. While that is so, one may ask, to what extent are those theories one could tentatively ascribe to this movement still valid? A rapid glance shows that many instances of "postmodern thought" do still have appeal and practical use, and remain undeterred by their secular theoretical opponents. And all the more so at a time when the term "postmodernism" has become almost worn out.

This collection of essays by leading scholars and artists aims at a reassessment of the undeniable achievements of what is, despite the trivialization of some of its philosophical stances, still a far-reaching, interdisciplinary movement. So the book contributes to a rehabilitation of postmodernism approaching the great variety of what could be termed "postmodern attitudes," and pointing to the relevance of some of its perspectives in order to come to terms with the future. As Román Álvarez, editor of the work, rightly points out, postmodernism is far from the usual academic climbing on the bandwagon, it "does not amount to a mere fashion, a mere word devoid of meaning that one is bound to use at random; it is much more than a movement invented by scholars in order to write about and make their livelihood from it. Postmodernism is a meditation on the society we live in, an attitude (or, rather, several attitudes), variegated ways of living that coexist, or should coexist, in peace." 